\title{
Relacje wynagrodzenia i wydajności czynnika pracy w rolnictwie na tle gospodarki narodowej i jej sektorów w Polsce w okresie 2005-2012
}

Streszczenie: W artykule podejmowana jest kwestia relacji między wynagrodzeniem czynnika pracy a jego wydajnością. Analiza jest prowadzona porównawczo dla rolnictwa i wybranych sektorów oraz całej gospodarki narodowej w ujęciu statycznym i dynamicznym. Relacja ta informuje o tym, czy wynagrodzenie wynika z wydajności. Podstawą teoretyczną do takiego ujęcia jest równowaga producenta i tzw. warunki zerowe zysków oraz kwestia alokacji i podziału w układzie sektorowym. W pierwszym zakresie pokazuje to, czy wydajność jest i w jakim zakresie źródłem finansowania wynagrodzenia w danym sektorze. W drugim, jaka jest racjonalność w międzysektorowej alokacji czynnika pracy i w podziale wartości dodanej. Między innymi wskazywać to może, czy rolnictwo korzysta, czy traci w tym podziale w relacji do zróżnicowania w wydajności czynnika. Rozumowanie prowadzone jest wpierw analitycznie, wyprowadzone zostają formuły zbliżone do koncepcji jednostkowych kosztów pracy i dowód teoretyczny. Następnie - empirycznie na podstawie wyprowadzonego autorsko podejścia z wykorzystaniem przede wszystkim ilustracji graficznych.

Słowa kluczowe: relacja wynagrodzenia do wydajności czynnika pracy; koszty jednostkowe pracy

\section{Problem i podejście}

Kluczową kwestią dla oceny racjonalności gospodarowania jest kształtowanie się relacji wynagrodzenia czynnika produkcji do jego produkcyjności. Czynniki produkcji to oczywiście kapitał fizyczny (maszyny, urządzenia, materiały i technologia) oraz praca (zatrudnieni w wymiarze ilościowym i jakościowym), a także

Autor jest pracownikiem naukowym Instytutu Ekonomiki Rolnictwa i Gospodarki Żywnościowej Państwowego Instytutu Badawczego w Warszawie, ul. Świętokrzyska 20, 00-002 Warszawa, a także Wyższej Szkoły Finansów i Zarządzania w Warszawie, ul. Pawia 55, 01-030 Warszawa (e-mail: wrembisz@gmail. com). 
czynnik ziemia (w istocie włączany w czynnik kapitału) ${ }^{1}$. W sensie mikroekonomicznym ta relacja wiąże się $\mathrm{z}$ równowagą producenta i jest podstawą maksymalizacji jego funkcji celu. Producent maksymalizujący zysk jako funkcję celu nie może sobie pozwolić na sytuację, w której wynagrodzenie czynnika jest wyższe niż jego produkcyjność. Musiałby znaleźć jakieś zewnętrzne źródło sfinansowania tej różnicy lub zbankrutować. W sensie zaś makroekonomicznym i sektorowym ta relacja wiąże się z alokacją i podziałem. Jeśli w tym przekroju analizy występuje wyższe wynagrodzenie danego czynnika produkcji (czy czynników produkcji) niż jego produktywność (zwłaszcza produktywność przeciętna) w jednym czy kilku sektorach, a w innych jest odwrotnie, to wskazuje to na nieefektywną alokację. $\mathrm{Z}$ drugiej strony, w sensie podziału, może to wskazywać na pewne wyrównywanie różnic $\mathrm{w}$ wynagrodzeniach jako skutek transferów wartości dodanych $\mathrm{z}$ jednych sektorów do drugich. Ma to oczywiście związek z sektorową efektywnością gospodarowania i związanymi z tym zmianami strukturalnymi, a w wymiarze praktycznym ma wpływ na sektorową konkurencyjność produkcji. Szczególne miejsce w tego typu podejściu zajmuje sektor rolnictwa. Już od powstania modeli Kuznetsa i Lewisa wiadomo, że rolnictwo może charakteryzować się mniej korzystnymi relacjami w tym względzie. Pośrednio znajduje to odzwierciedlenie w kwestii agrarnej i podstawach polityki rolnej. Stąd znane postulaty wynikające $\mathrm{z}$ tych modeli o konieczności zmian strukturalnych. W ujęciu makroekonomicznym odnoszonym jedynie do gospodarki jako całości zachowanie racjonalnej zasady, tj. że produktywność czynników finansuje ich wynagrodzenie, ma zasadnicze znaczenie dla zrównoważonego rozwoju i konkurencyjności danej gospodarki.

$\mathrm{W}$ artykule na podstawie przyjętego podejścia analitycznego i założenia definiującego podejmujemy próbę syntetycznej empirycznej oceny relacji wynagrodzenia do wydajności czynnika pracy w rolnictwie w porównaniu do całej gospodarki i wybranych jej sektorów. To nawiązanie do wspomnianego wyżej ujęcia makroekonomicznego sektorowego. W pewnym sensie ilustruje to też kwestię struktury gospodarki $\mathrm{w}$ nawiązaniu do wskazanych modeli, $\mathrm{w}$ tym pośrednio - kwestię rolnictwa w aspekcie dostosowania go do całej gospodarki, jeśli mowa o relacjach produktywności i wynagrodzenia czynników, m.in. czynnika pracy. Ujęty w tym jest także niejako efekt podziału w gospodarce narodowej w sensie transferów wartości dodanej. W tej ostatniej kwestii niekiedy przyjmowany jest pogląd o transferze wartości dodanej $\mathrm{z}$ rolnictwa, zatem ta analiza może być także przyczynkową weryfikacją tego poglądu. Punktem wyjścia są jednak założenia mikroekonomiczne co do wyboru producenta.

1 Problem podziału produktu (czy wartości dodanej) pomiędzy czynniki biorące udział w jego tworzeniu jest kwestią kluczową w ekonomii. Tu przyjmujemy, jak John Bates Clark, że „każdy z czynników produkcji [...] wynagradzany jest zgodnie z wartością dodaną, jaką wnosi do całego dochodu z produktu, czyli zgodnie ze swoją marginalną produktywnością"; za: Skousen 2012, s. 319. 
W artykule zarówno w części teoretycznej, jak i empirycznej przyjmujemy zasadę ceteris paribus oraz inne uproszczenia, aby wydobyć istotę omawianego problemu i nadać analizie charakter ogólności ${ }^{2}$. Celem artykułu jest synteza wyników badań i pokazanie wagi problemu oraz poddanie tego pod szerszy osąd naukowy.

\section{Podstawa teoretyczna relacji wynagrodzenia i wydajności}

Podstawą teoretyczną, z której można wywodzić zarysowany problem i podejście, jest równowaga producenta. $\mathrm{W}$ sensie ogólnym, producent maksymalizując swoją funkcję celu, powinien równoważyć poziom wynagrodzeń z produktywnością krańcową każdego z czynników. Analogicznie zwiększanie wynagrodzeń tych czynników powinien bilansować ze wzrostem ich produktywności. Zatem przedstawiając zagadnienie optymalizacji warunkowej producenta wykorzystującego dwa czynniki wytwórcze, mamy:

$$
R=Y \cdot c_{y} \rightarrow \max
$$

przy:

$$
K \cdot C_{k}+L \cdot C_{L}=m^{k}
$$

oraz:

$$
\Pi=R-m^{k},
$$

gdzie: $\Pi$ - zysk, $Y$ - wielkość produkcji, $c_{Y}$ - cena otrzymywana, $R$ - przychód, $K$ - zaangażowanie czynnika kapitału, dla producenta rolnego ujęte jest tu zaangażowanie czynnika ziemi, $C_{K}$ - wynagrodzenie czynnika kapitału (w istocie stopa procentowa i renta), $L$ - zaangażowanie czynnika praca, $C_{L}$ - wynagrodzenie czynnika praca (u producenta jako wielkość resztowa, czyli dochód z pracy), $m^{k}$ - ograniczenie dochodowe-kosztowe, czyli środki przeznaczone na pokrycie wynagrodzenia zaangażowanych czynników wytwórczych.

W warunkach równowagi konkurencyjnej, a to najczęściej charakteryzuje sytuację danych (pojedynczych) producentów rolnych na rynku, mamy:

$$
\Pi=\left\{Y \cdot c_{Y}-\left(K \cdot c_{K}+L \cdot c_{L}\right)\right\} \Rightarrow 0 .
$$

$2 \mathrm{~W}$ artykule nawiązujemy do rozumowania (pogłębiając je, zmieniając, aktualizując oraz syntetyzując) ujętego wstępnie czy zapoczątkowanego w Rembisz, Sielska 2014a, Rembisz, Sielska 2014b oraz Bezat-Jarzębowska, Rembisz, Sielska 2012, gdzie znajdują się też szczegółowe odniesienia do pomiaru przyjętych w analizie empirycznej kategorii - wynagrodzeń czynnika pracy i jego zatrudnienia, wartości dodanej. 
Producenci osiągają równowagę, czy zyski zerowe, bo zrównują się wynagrodzenia z produktywnościami czynników wytwórczych, dla egzogennych dla nich cen produktów i cen czynników. W tej sytuacji krańcowe produktywności czynników pracy i kapitału wyznaczają ich poziom wynagrodzenia (dla danych cen jako stałych, a więc pomijanych w różniczkowaniu) u producenta (Rembisz, Sielska 2015):

$$
-\frac{\frac{\partial Y}{\partial L}}{\frac{\partial Y}{\partial K}}=-\frac{c_{L}}{c_{K}} .
$$

Można to ująć rozdzielnie, by bardziej wyeksponować warunek, że poziom wynagrodzeń jest wyznaczany przez produktywność krańcową danego czynnika - co zależy od producenta, i uzyskiwane ceny (tu jako zmienną) - co nie zależy od producenta:

$$
c_{K}=f\left(\frac{\partial y}{\partial k} \cdot c_{Y}\right) \rightarrow c_{L}=f\left(\frac{\partial y}{\partial L} \cdot c_{Y}\right) .
$$

W sensie relacji technicznych, dla danych cen produktów jako stałych, producent, maksymalizując swoją funkcję celu, stara się znajdować w punkcie zrównania produkcyjności przeciętnej i krańcowej czynnika ${ }^{3}$. To, zgodnie z teorią funkcji produkcji, wyznacza sferę racjonalnego gospodarowania w sensie efektywności technicznej. Mamy więc optymalne poziomy $\left(K^{*}, L^{*}\right)$ zaangażowania czynników produkcji:

$$
K^{*}=\frac{\partial y}{\partial K}=\frac{y}{K} \quad L^{*}=\frac{\partial y}{\partial L}=\frac{y}{L} .
$$

Wynagrodzenie zatem czynnika wytwórczego jest wprawdzie wyznaczane przez produkcyjność krańcową, jednak w istocie jest odnoszone do produkcyjności przeciętnej (wyższej niż krańcowa w sferze racjonalnego gospodarowania), od której nie powinno być wyższe. Zatem dla problemu postawionego $\mathrm{w}$ artykule powyższe relacje możemy zapisać w następującej postaci ${ }^{4}$ :

$$
u_{L}=c_{L} / \frac{y}{L}=\frac{c_{L}}{w_{L}} .
$$

3 To znaczy zwiększać zaangażowanie danego czynnika do tego punktu.

$4 \mathrm{~W}$ przypadku ujęcia cen nie jako stałej, ale jako bieżących, mamy: $u_{L}=\frac{c_{L}}{w_{L} \cdot c_{Y}}$. 
Wynagrodzenie jest tu odnoszone do przeciętnej wydajności czynnika pracy, dla danych cen jako stałych, tak jak jest to ujmowane w funkcji produkcji. Zależność taka jest znana jako jednostkowe koszty pracy (Unit Labour Cost - ULC) i traktowana jako miernik empiryczny konkurencyjności kosztowej oraz stanowi podstawę uzyskiwanej opłacalności dla indywidualnych producentów lub ich grup czy całych sektorów i gospodarek narodowych. W ujęciu dynamicznym można to zapisać5:

$$
\Delta u_{L}=\Delta c_{L} / \Delta w_{L} .
$$

W naszym podejściu te wskaźniki informować będą o relacjach wydajnościowo-dochodowych pomiędzy sektorami gospodarki, co wiąże się także z podziałem wypracowanej w gospodarce wartości. W kontekście sektora rolnictwa informuje to o jego udziale w owym podziale.

\section{Implikacje przyjętego podejścia}

Implikacje poznawcze i praktyczne przyjętego podejścia to głównie diagnoza. Wskaźniki te informują bowiem o tym, czy poziom i wzrost wynagrodzenia czynnika pracy jest finansowany przez jego wydajność i jej zmiany. W przypadku, w którym wynagrodzenia są wyższe od wydajności czynnika pracy (także czynnika kapitału lub czynnika ziemia), muszą występować inne źródła finansowania tego wynagrodzenia. Oczywiście akceptowaną ekonomicznie, w sensie równowagi, konkurencyjności, efektywności produkcji (w tym efektywności alokacyjnej, a także podziału ${ }^{6}$ ), jest sytuacja, gdy poziom wynagrodzenia oraz jego wzrost wynikaja z wydajności i jej zmian. To świadczy o racjonalności gospodarowania i zachowane są warunki równowagi producentów jako podstawy mikroekonomicznej.

5 Co jest równoważne: $\frac{\partial u_{L}}{u_{L}}=\frac{\partial c_{L}}{c_{L}}-\frac{\partial w_{L}}{w_{L}}$, czyli zmiany omawianego wskaźnika następują pod wpływem zmian wydajności i wynagrodzeń, dla danych cen jako stałej. Gdyby ująć ceny bieżące, to mamy: $\frac{\partial u_{L}}{u_{L}}=\frac{\partial c_{L}}{c_{L}}-\left(\frac{\partial w_{L}}{w_{L}}+\frac{\partial c_{Y}}{c_{Y}}\right)$, gdzie zmiany omawianego wskaźnika następują także pod wpływem zmian cen otrzymywanych. Występuje tu kwestia źródeł zmian wskaźnika kosztów jednostkowych, analizę tego zostawiamy na oddzielną okazję.

6 Racjonalność w sensie alokacji odnosimy do produktywności czynników, sprawiedliwość zaś w sensie podziału odnosimy do ich wynagrodzeń. Można to wiązać z efektami polityki. Można przyjąć, że jeśli zróżnicowanie w zakresie wynagrodzeń jest mniejsze niż w zakresie wydajności, to i można wnioskować, że sprawiedliwość podziału była ważniejszym kryterium niż efektywność. Polityka dominowała więc nad regulacją rynkowo-efektywnościową. Tym samym, gdy rolnictwo w zakresie wynagrodzeń różni się mniej od innych działalności niż w zakresie wydajności, zjawisko to należy przypisać pozytywnemu efektowi czy sukcesowi polityki rolnej (Rembisz, Sielska 2014b). 
W ujęciu bardziej fundamentalnym, gdy w jednym sektorze wynagrodzenie przewyższa wydajność czynnika, a w innych może być sytuacja odwrotna, wskazywać to może na nieracjonalną alokację międzysektorową tego czynnika, w naszym przypadku - czynnika pracy. W odniesieniu np. do sektora rolnictwa w relacji do całej gospodarki oznaczać to może nie tylko konieczność zwiększenia wydajności czynnika pracy w rolnictwie, lecz także wskazywać na możliwość wzrostu wydajności czynnika pracy w skali całej gospodarki dzięki migracji zatrudnionych $\mathrm{w}$ rolnictwie do innych sektorów. Znane jest to między innymi ze wspomnianych modeli Lewisa i Kuznetsa czy Schultza i było analitycznie objaśnione przez model Jorgensona ${ }^{7}$. Podejście proponowane w tym artykule może się też, jak zasygnalizowaliśmy, odnosić do kwestii ewentualnego transferu nadwyżki wartości z rolnictwa do innych sektorów, co jest często podnoszone w literaturze ekonomiki rolnictwa ${ }^{8}$.

\section{Relacja wynagrodzenia do wydajności w literaturze}

Takie podejście, jak przedstawione wyżej, jest znane w literaturze i zbliżone do wskaźników jednostkowych kosztów pracy (ULC). Definiowane jest w ogólności jako iloraz kosztów nakładu czynnika pracy w stosunku do jego wydajności jednostkowej. Nie miejsce tu na szczegółowe odnoszenie się do tego wskaźnika, który dla naszej analizy ma ujęcia zbyt szczegółowo-kosztowe, które mogą zaciemnić istotę analizowanej kwestii ${ }^{9}$. Niemniej zgłaszamy kilka uwag, które bardziej pogłębiają podstawy metodyczne naszej analizy. Koszt nakładu czynnika pracy w tych ujęciach jest obliczany jako iloczyn wynagrodzenia czynnika pracy i liczby pracowników. Produktywność czynnika pracy jest rozumiana jako relacja wytworzonego produktu do liczby pracowników, czyli jak w podejściu powyżej. Pomiar jednostkowych kosztów pracy na poziomie pojedynczego przedsiębiorstwa nie

7 Jorgenson w swoim modelu odnosi się do kwestii dysparytetu dochodowego, czyli zróżnicowania wynagrodzeń czynnika pracy w przemyśle i rolnictwie (wage differentials between industry and agriculture). Zgodnie z prawidłowością Webera-Fechnera o proporcjonalności efektów zakładać można, że efekt, który może wywołać przesunięcie zatrudnienia czynnika pracy z rolnictwa do przemysłu, jest w przybliżeniu proporcjonalny do wskaźnika wynagrodzeń w przemyśle w relacji do jego wydajności. Jeśli wskaźnik bliski określeniu „dysparytet dochodowy” to: $(\mu-1)$, wtedy wielkość wynagrodzeń czynnika pracy w obu sektorach (w całej gospodarce) będzie określona jako $w M+\mu w A=(1-\sigma) X+q Y$, gdzie: $w M$ - wielkość wynagrodzeń w przemyśle, $\mu w A$ - dochody w rolnictwie; $(1-\sigma), q$ - parametry strukturalne udziału czynnika pracy w wartości produkcji w przemyśle i rolnictwie, $X, Y$ - wartość produkcji w przemyśle i w rolnictwie. A sama stopa wzrostu wynagrodzenia czynnika pracy np. w przemyśle: $(1-\sigma) x=w$, gdzie $w$ jest definiowane przez jednostkową wydajność tego czynnika: $x$ oraz relatywnym udziałem tego czynnika wartości produktu: $(1-\sigma)$. Por. szerzej Rembisz, Floriańczyk 2014.

8 Podnoszona przez poznańską szkołę ekonomii rolnej skupioną wokół Andrzeja Czyżewskiego, dyskusje na ten temat zawiera np. praca Rembisz 2013.

9 W tej części artykułu wykorzystujemy po zmianach elementy analizy z Rembisz, Sielska, Pawłowska 2016, gdzie znajdują się źródłowe odniesienia do literatury i dowody. 
budzi wątpliwości. Oszacowanie zaś tak ujmowanych jednostkowych kosztów pracy dla całej gospodarki bądź poszczególnych jej sektorów, co ważne dla naszej analizy, możliwe jest jedynie po zastosowaniu uproszczenia polegającego na utożsamieniu ilości wytworzonego produktu $(y) \mathrm{z}$ realną wartością dodaną wytworzoną $\mathrm{w}$ danej branży ${ }^{10}$. Takie założenie też przyjmujemy. $\mathrm{W}$ takim ujęciu wskaźnik ten jest często rozpatrywany jako miara konkurencyjności kosztowej danego sektora lub gospodarki. Uznaje się za zasadne takie uogólnienia tylko wtedy, jeżeli zagregowane jednostkowe koszty pracy dla danego sektora lub całej gospodarki są tożsame z przeciętnymi jednostkowymi kosztami pracy dla wszystkich przedsiębiorstw $\mathrm{z}$ danego sektora (gospodarki), co przyjmujemy jako założenie w naszej analizie, czyli spełniony jest warunek:

$$
U L C=\sum_{i=1}^{k}\left\{\left(\frac{c_{y i} y_{i}}{\sum_{i=1}^{k} c_{y i} y_{i}}\right) *\left(\frac{C_{L i} l_{i}}{c_{y i} y_{i}}\right)\right\}=\sum_{i=1}^{k} \varphi^{i}\left(\frac{U L C_{i}}{c_{y i}}\right),
$$

gdzie: $p_{i}$ oznacza cenę produktu ustaloną przez $i$-te przedsiębiorstwo, $y_{i}$ - wielkość produkcji $i$-tego przedsiębiorstwa, $C_{L i}$ - przeciętne wynagrodzenie czynnika pracy $\mathrm{w} i$-tym przedsiębiorstwie, $l_{i}$ - wielkość zatrudnienia $\mathrm{w} i$-tym przedsiębiorstwie oraz $\varphi^{i}$ - udział $i$-tego przedsiębiorstwa w realnej wartości dodanej wytworzonej $\mathrm{w}$ danej branży (gospodarce). Analizowany wskaźnik to suma ważonych przeciętnymi jednostkowymi kosztów pracy dla poszczególnych producentów oraz cen $p_{i}$, uzyskiwanych przez każde przedsiębiorstwo ${ }^{11}$.

Druga ważna uwaga to to, iż na wartość ULC i jego zmiany większy wpływ może mieć zmiana poziomu wynagrodzenia (tzw. wage effect) lub poziom wydajności pracy (tzw. labour productivity effect) i na odwrót oczywiście w ujęciu relatywnym.

10 Istnieje możliwość rozpatrywania łącznego wynagrodzenia i/lub produktywności czynnika pracy zarówno w ujęciu nominalnym, jak i realnym. Podejściem szerzej stosowanym, m.in. przez Europejski Bank Centralny, Komisję Europejską oraz OECD, jest traktowanie ULC jako relacji łącznych nominalnych kosztów w przeliczeniu na jednego pracownika do produktywności pracy w ujęciu realnym. Odmiennie podejście prezentuje Eurostat, traktując ULC jako iloraz łącznych nominalnych kosztów w przeliczeniu na jednego pracownika do nominalnej produktywności pracy. W analizie rynku pracy w Polsce, przeprowadzanej przez Narodowy Bank Polski, stosowane są natomiast następujące podejścia obliczania jednostkowych kosztów pracy: $U L C=\frac{L_{B A E L} w_{G N}}{P_{r P K B}}, U L C=\frac{L_{G N} w_{G N}}{P_{r P K B}}, U L C=\frac{L_{G N} w_{G N}}{P_{G V A}}$, gdzie: $L_{B A E L}$ oznacza liczbę pracujących według BAEL, $L_{G N}$ - wielkość zatrudnienia w gospodarce narodowej, $w_{G N}$ - przeciętne wynagrodzenie w gospodarce narodowej, $P_{r P K B}$ - wolumen produkcji na podstawie realnego PKB i $P_{G V A}$ - wolumen produkcji na podstawie wartości dodanej brutto.

11 Kontynuując rozpatrywanie wartości dodanej w ujęciu realnym, pominięto wpływ delatora wartości dodanej, wyszczególnionego przez Jesusa Felipe i Utsav Kumar, jako dodatkowego czynnika kształtującego zagregowane jednostkowe koszty pracy. 
Udział w ULC efektów zmiany wydajności czynnika pracy i jego wynagrodzenia w okresie $t=1 \mathrm{w}$ porównaniu do okresu $t=0$ analizuje się na podstawie:

$$
\frac{U L C_{1}}{U L C_{0}}=\left(\left(\frac{w_{1} L_{1}}{Y_{1}} / \frac{w_{0} L_{0}}{Y_{0}}\right) /\left(\frac{w_{1}}{w_{0}}\right)^{\frac{1}{2}\left(s_{L 0}+s_{L 1}\right)}\right) *\left(\frac{w_{1}}{w_{0}}\right)^{\frac{1}{2}\left(s_{L 0}+s_{L 1}\right)},
$$

gdzie: $w_{i}$ oznacza wynagrodzenie czynnika pracy w $i$-tym okresie, $L_{i}$ - wielkość zatrudnienia w $i$-tym okresie, $Y_{i}$ - wielkość produkcji w $i$-tym okresie, $s_{L i}$ - udział wynagrodzenia czynnika pracy w łącznych kosztach $\mathrm{w} i$-tym okresie oraz $i=\{0,1\}$.

Tego wątku w analizie nie podejmujemy. Wpływ efektów zmian wynagrodzenia w relacji do zmian wydajności i odwrotnie znajduje wyraz w wartościach syntetycznych wskaźników będących przedmiotem analizy empirycznej w dalszej części artykułu. Oczywiście w sensie ekonomicznym byłoby korzystne, gdyby oba efekty pozostawały $\mathrm{w}$ stałej proporcji, tj. wynagrodzenie wynikało $\mathrm{z}$ wydajności, ale też wynagrodzenie wymuszało wzrost wydajności czynnika. Są to oddzielnie ważne dla racjonalności ekonomicznej i równowagi kwestie. Odnotujmy tylko, że np. wzrost wynagrodzeń powinien skłaniać producentów rolnych do zwiększania relacji czynnika kapitału rzeczowego i czynnika ziemia do czynnika pracy, a te relacje (w istocie techniki wytwarzania) warunkować zwiększanie wynagrodzenia. Te kwestie podejmowaliśmy w innych pracach (Bezat-Jarzębowska, Rembisz, Sielska 2013).

\section{Interpretacja ilościowa wskaźnika wynagrodzenia do wydajności}

Wyliczonym wskaźnikom $u_{L}$ oczywiście można nadać określone wielkości normatywne. Przyjmujemy, że lepiej jest, gdy wartość $u_{L}$ jest mniejsza niż większa od jedności. Gdy uzyskujemy $u_{L} \leq 1$, to wskazuje to, że z nawiązką źródłem finansowania wynagrodzenia czynnika pracy jest wydajność pracy, czyli mamy do czynienia $\mathrm{z}$ racjonalnym gospodarowaniem. Odwrotna relacja: $u_{L} \geq 1$ oczywiście wskazuje na nieracjonalność gospodarowania i alokacji, i wyższe wynagrodzenia niż wydajność muszą być finansowane ze źródeł zewnętrznych lub kosztem wynagrodzenia innego zaangażowanego czynnika produkcji. W takim ujęciu tak wyliczone wskaźniki mogą być pomocne dla przyjęcia lub odrzucenia hipotezy o powołanym wyżej ewentualnym transferze nadwyżki z rolnictwa. Przede wszystkim jednak służą one do oceny procesów alokacji i podziału w ujęciu sektorowym.

Z perspektywy mikroekonomicznej, z warunków równowagi producenta, jeśli mamy: $u_{L} \neq 1$, to może to wskazywać na zachwianie tej równowagi. Gdy $u_{L} \geq 1$, to możemy mieć do czynienie $\mathrm{z}$ pogarszaniem się racjonalności i obniżaniem konkurencyjności zarówno w sensie relatywnym, jak i absolutnym. W konsekwencji 
muszą się też znajdować inne poza wydajnością źródła finansowania wynagrodzenia pracy. W przypadku producentów rolnych trzeba to odnosić do renty politycznej jako źródła kształtowania dochodów ${ }^{12}$. Z drugiej strony, jeśli wartość wskaźnika $u_{L} \leq 1$, to wprawdzie wskazuje to na konkurencyjność, jednakże ten pozytywny efekt może być osiągany kosztem wynagrodzeń - niskich dochodów. Jeśli: $u_{L}=1$, to producent jest $w$ równowadze, występuje sytuacja tzw. zerowych zysków (zero profit conditions), wydajność czynnika pracy w całości finansuje jego wynagrodzenie lub odwrotnie, wypracowana wartość dodana jest równa wynagrodzeniu dla danych cen produktów (jako danych).

Wskaźnik $\Delta u_{L}$ jako relacja stóp wzrostu wynagrodzenia i wydajności powinien się kształtować też blisko jedności (można to ujmować w skali 100\%). Wyższe wartości od jedności: $\Delta u_{L}>1$ mogą wskazywać na pogarszanie się racjonalności i konkurencyjności w danym sektorze, niższe: $\Delta u_{L}<1$ - na odwrotne procesy. Relacje wzrostowe obrazowane w $\Delta u_{L}$ dają bardziej obiektywne podstawy do wnioskowania niż $u_{L}$ (bo mogą być mniej obciążone ewentualnymi błędami wymiarowości pozyskiwanych danych liczbowych). Odnosi się to zwłaszcza do oceny perspektyw co do racjonalności i konkurencyjności. Może też być podstawą do oceny skutków polityki rolnej.

\section{Analiza porównawcza wynagrodzenia i wydajności w rolnictwie i gospodarce ogółem}

Wyniki przedstawione na poniższych wykresach mogą stanowić przybliżoną podstawę do syntetycznej analizy, będącą niejako empiryczną weryfikacją przyjętego podejścia. Ważne są tu jedynie proporcje i relacje. To, co jest łatwe do uchwycenia $\mathrm{z}$ obrazu na rysunku $1 \mathrm{i}$ co jest związane $\mathrm{z}$ istotą przyjętego podejścia, to to, że rolnictwo wyraźnie odstaje pod względem wydajności in minus od pozostałych ujętych w analizie sekcji i całej gospodarki. Może to oznaczać potencjalne źródło wzrostu wydajności czynnika pracy w całej gospodarce związane $\mathrm{z}$ jego alokacją. Nie jest to zaskoczeniem, bo zjawisko jest znane w kontekście powoływanych modeli. Bardziej pesymistyczna konstatacja brzmi, że ten dystans się nie zmniejsza, a raczej powiększa. Dla empirycznej weryfikacji przyjmowanego podejścia nie ma to jednak zasadniczego znaczenia. Istotne jest tu porównanie z kształtowaniem się wynagrodzenia tego czynnika, co pokazane jest na rysunku 2 .

Jak widać $\mathrm{z}$ wykresów na rysunku 2 , zróżnicowania w poziomie wynagrodzenia $\mathrm{w}$ analizowanych sekcjach prawie nie ma, rolnictwo wraz z leśnictwem wprawdzie odstaje w tym względzie od pozostałych, jednak niewiele. W każdym razie, odstaje

12 Jak wspominaliśmy, było to przedmiotem analizy w Bezat-Jarzebowska, Rembisz, Sielska 2013. 
zdecydowanie mniej pod tym względem, niż ze względu na wydajności tego czynnika. Jest to ważna konstatacja. Wskazywać bowiem może, że w aspekcie podziału sekcja rolnictwa $z$ leśnictwem nie jest pokrzywdzona, a wręcz odwrotnie. Trudno zatem mówić o transferze wartości z rolnictwa, to raczej rolnictwo korzysta na podziale międzysektorowym i z renty politycznej.

Analiza rysunków 1 i 2 w pewnym sensie jest weryfikacją empiryczną wspominanych wyżej modeli dla obecnego etapu rozwoju gospodarczego, co nie było wszelako celem tego artykułu.

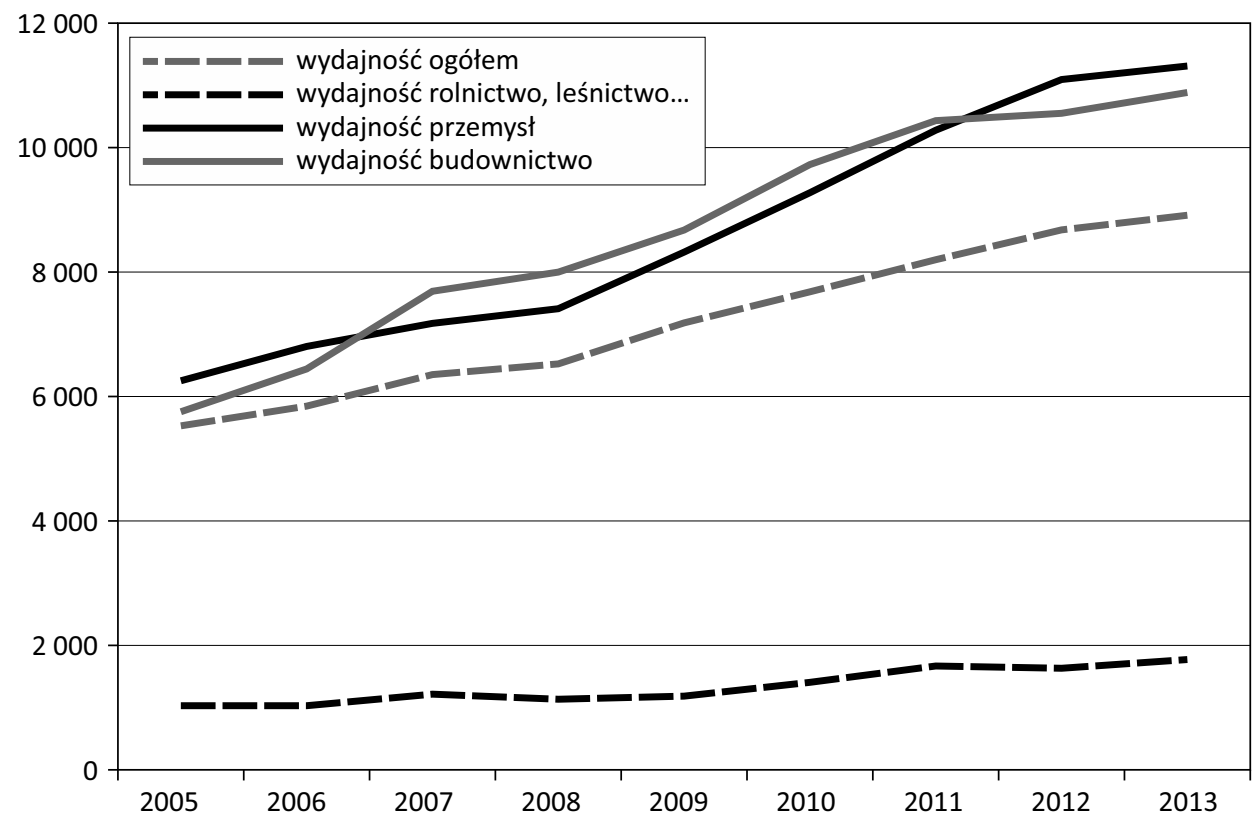

Rolnictwo, leśnictwo... - sekcja A wg PKD 2007 (rolnictwo, leśnictwo, rybactwo, rybołówstwo); przemysł sekcje B, C, D, E; budownictwo - sekcja F; wydajność - wartość dodana na jednego pracującego (miesięcznie).

Rysunek 1. Porównanie wydajności czynnika pracy w sektorach gospodarki narodowej

Figure 1. A comparison of labour productivity among sectors of the national economy

Źródło: opracowanie własne na podstawie Banku Danych Lokalnych (dalej BDL) GUS.

Source: own study on the basis of the Local Data Bank of CSO.

Oczywistą jednakże konsekwencją poczynionych obserwacji, zgodnie z przyjętym podejściem, jest kształtowanie wskaźnika relacjonującego wynagrodzenie do wydajności czynnika, czyli $u_{L}$. To pokazujemy na rysunku 3. 
Relacje wynagrodzenia i wydajności czynnika pracy w rolnictwie...

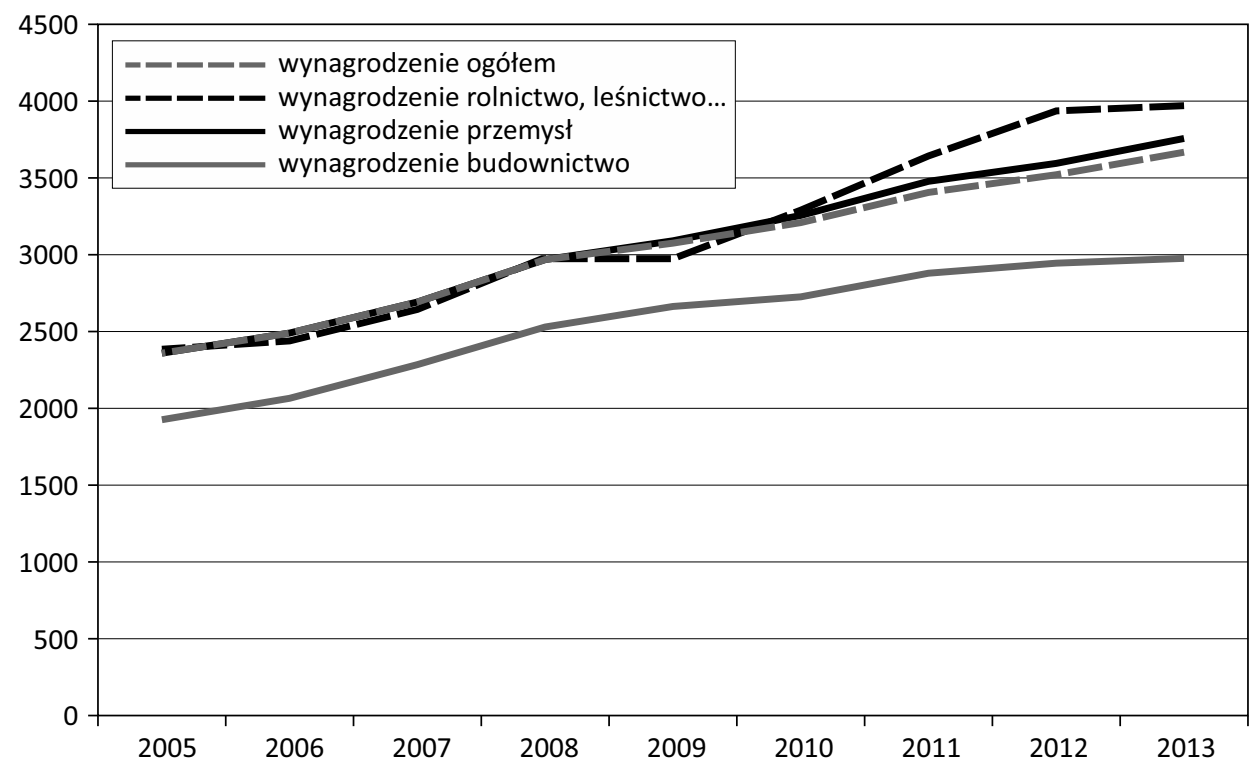

Rysunek 2. Porównanie wynagrodzenia czynnika pracy w gospodarce ogółem i analizowanych sekcjach

Figure 2. A comparison of labour remuneration among the sectors and national economy

Źródło: opracowanie własne na podstawie BDL GUS.

Source: own study on the basis of the Local Data Bank of CSO.

Kształtowanie się wielkości empirycznych wskaźnika, które jest zobrazowane na rysunku 3, nie zaskakuje. Wskaźnik ten w wyrazie ilościowym w odniesieniu do rolnictwa przyjmuje wartości grubo powyżej jedności, w pozostałych sekcjach i całej gospodarce narodowej kształtuje się poniżej jedności. Różnica jest znacząca, by nie powiedzieć szokująca. To bardzo zła wiadomość $\mathrm{z}$ tego punktu widzenia, w odniesieniu do tego sektora czy sekcji. Oznacza to, że w sekcji A, rolnictwa i leśnictwa, wynagrodzenie czynnika pracy jest znacznie wyższe niż jego wydajność. $\mathrm{W}$ pozostałych sektorach i całej gospodarce narodowej jest odwrotnie, wynagrodzenie czynnika pracy jest niższe niż wydajność tego czynnika. Zgodnie z przyjętym podejściem i założeniami teoretycznymi wskazuje to na kilka co najmniej spraw.

Po pierwsze, rolnictwo, jak z tego wynika, korzysta w podziale wartości w gospodarce, wynagrodzenie jest wyższe niż wydajność czynnika pracy. Na to już wskazywaliśmy wyżej. Trudno zatem mówić o transferze wypracowanej w rolnictwie wartości do innych sektorów, co, jak wspominaliśmy, jest rozpowszechnionym poglądem. 
Po wtóre, muszą więc występować pozawydajnościowe źródła finansowania wynagrodzenia czynnika pracy w rolnictwie. Środki finansowe są efektem transferu wartości z innych działów albo pochodzą ze wspólnej polityki rolnej (będącej obecnie finansowanej z obciążeń innych sektorów w innych krajach).

Po trzecie, te wyniki mogą wskazywać na niższą racjonalność gospodarowania $\mathrm{w}$ rolnictwie $\mathrm{w}$ porównaniu z pozostałymi sektorami i całą gospodarką, w sensie wyjściowej w tym podejściu równowagi producenta. Skutkiem tego de facto może być niższa konkurencyjność sektora, głównie w aspekcie efektywnościowo-kosztowym, i jego pełna zależność od dopłat czy płatności bardziej lub mniej bezpośrednich.

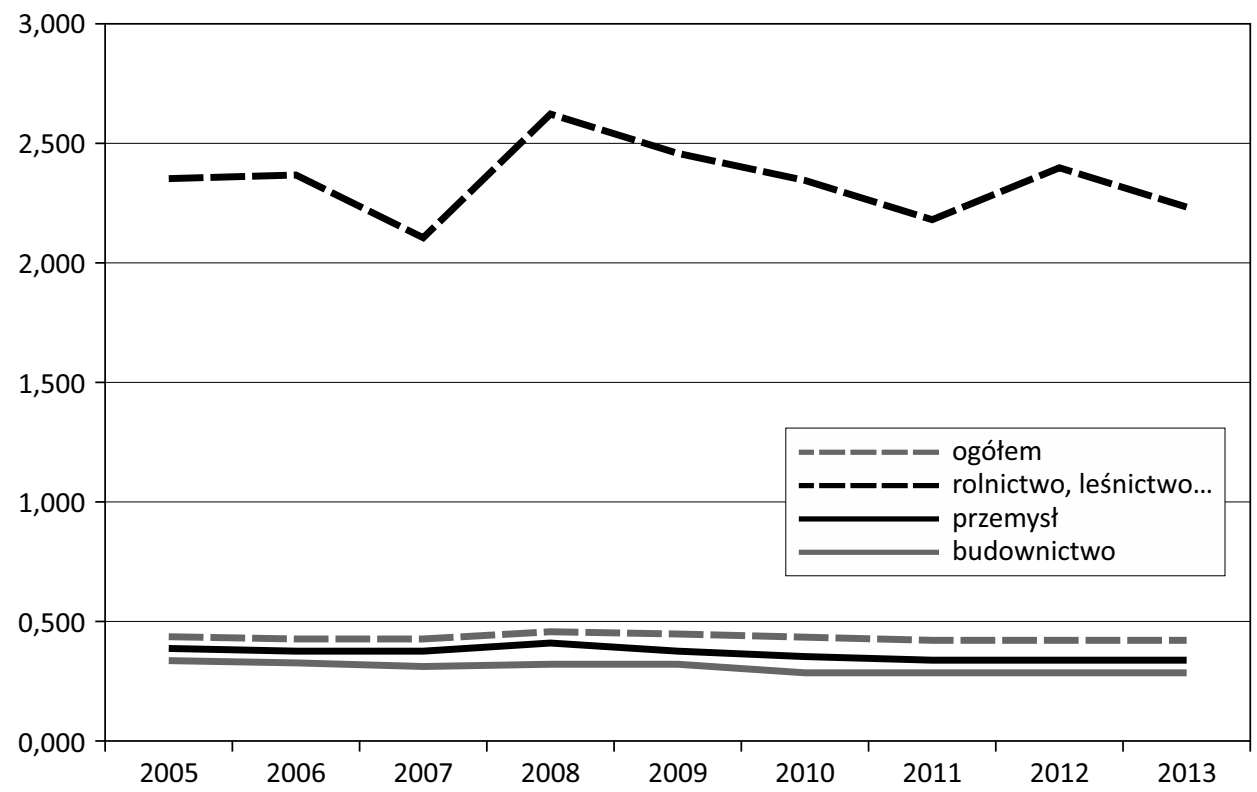

Rysunek 3. Porównanie relacji wynagrodzenia do wydajności w gospodarce ogółem i sektorach

Figure 3. A comparison of the relations between remuneration and productivity of labour factor among sectors of national economy

Źródło: opracowanie własne na podstawie BDL GUS.

Source: own study on the basis of the Local Data Bank of CSO.

Bez tych dopłat, zakładając, że muszą występować warunki równowagi producentów, by sektor się rozwijał i zachowywał konkurencyjność, musiałyby następować dwa procesy. Konieczne byłoby obniżanie wynagrodzenia czynnika pracy lub musiałaby się znacznie zwiększyć wydajność tego czynnika. Zmiany strukturalne, 
w tym głównie koncentracja, musiałoby tu być faktem. Jeśli nie te procesy, to musiałby nastąpić wzrost cen produktów rolnych dla sfinansowania tej różnicy. W tym rozumowaniu i analizie przyjmowaliśmy, że producenci nie mają wpływu na cenę, stąd wynagrodzenie czynnika winni dostosowywać do jego wydajności. Jak widać, w rolnictwie raczej to nie nastąpiło. Analizę tych problemów zostawiamy jednak na oddzielną okazję.

W sensie bardziej ogólnym powyższa analiza empiryczna może wskazywać, że $\mathrm{w}$ rolnictwie wynagrodzenie czynnika jest raczej przewartościowane w stosunku do jego wydajności, a w pozostałych sektorach odwrotnie.

\section{Analiza porównawcza zamian relacji wynagrodzenia do wydajności}

Powstaje pytanie, czy w analizowanej relacji w miarę upływu czasu coś się zmienia w kierunku pozytywnym. Zaczynamy od analizy dynamiki wydajności czynnika pracy (vide rys. 4). Wyniki empiryczne pozwalają na pewien optymizm. Analiza wykresów wskaźnika dynamiki wydajności czynnika pracy na tym rysunku pokazuje, że kształtuje się on we wszystkich sektorach i w całej gospodarce podobnie. Oznaczać to może, że sektor rolnictwa dostosował się, pod tym zasadniczym względem, do dynamiki zmian w całej gospodarce i jej pozostałych sektorów. Jest to pozytywny proces. Wyrównanie dynamiki wzrostu wydajności czynnika pracy to dobra podstawa do równowagi wzrostu w gospodarce narodowej, do ustalonej relacji, że wzrost wydajności czynnika pracy finansuje wzrost jego wynagrodzenia. Nie gwarantuje to jeszcze jednak wyrównania się poziomu wydajności czynnika pracy w ujęciu sektorowym.

Podobne konstatacje nasuwają się przy analizie wykresów na rysunku 5. Dynamika wzrostu wynagrodzeń czynnika pracy we wszystkich badanych układach jest bardzo podobna. To też jest obserwacja, która pozwala na pozytywną opinię, jeśli idzie o równowagę wzrostu w ujęciu sektorowym. Rolnictwo nie jest tu sektorem upośledzonym, co podnoszone było w tradycyjnych dualnych modelach wzrostu.

W rezultacie tak układających się wzajemnych relacji pomiędzy analizowanymi wyżej wykresami kształtowanie się najważniejszego w tej analizie wskaźnika: $\mathfrak{u}_{L}$, też daje podstawy do pozytywnych uwag. Obraz kształtowania się tego wskaźnika, czyli relacji między wzrostem wynagrodzenia i wydajności czynnika pracy, pokazany jest na rysunku 6. Wprawdzie w rolnictwie w okresie 2007-2010 wskaźnik ten nieznacznie przekraczał wartość jeden $\left(u_{L}>1\right)$, czyli wzrost wynagrodzeń przewyższał wzrost wydajności, jednakże w pozostałych latach kształtował się około wartości jeden. $\mathrm{W}$ takim zakresie lub poniżej wartości jeden $\left(u_{L}<1\right)$ ten wskaźnik kształtował się dla gospodarki ogółem i pozostałych analizowanych sektorów. Jest to pozytywna konstatacja, co może wskazywać na wysoką racjonalność procesów 
wzrostowych w gospodarce, na poprawę jej konkurencyjności oraz na zachowanie równowag producentów. Zachowana jest ustalona relacja, w której wzrost wynagrodzeń znajduje źródło finansowania we wzroście wydajności czynnika pracy. Rolnictwo od tego pozytywnego w swej istocie procesu nie odbiega in minus.

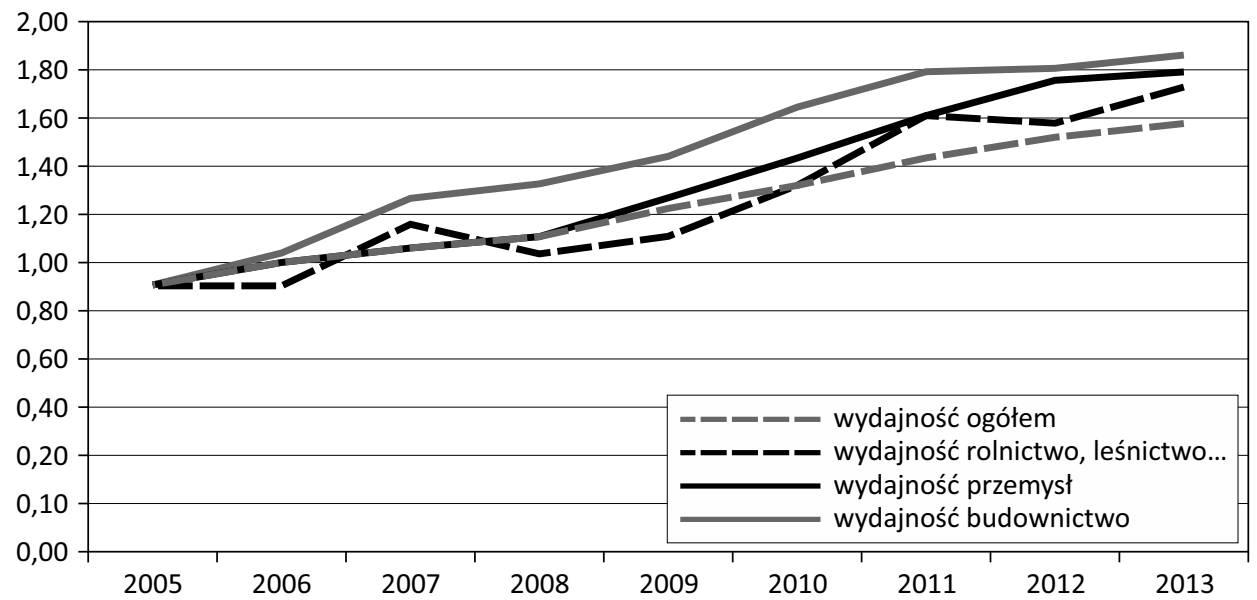

Rysunek 4. Porównanie dynamiki wydajności czynnika pracy w sekcjach $(2005=1)$ Figure 4. Index comparison of labour factor productivity over time $(2005=1)$

Źródło: opracowanie własne na podstawie BDL GUS.

Source: own study on the basis of the Local Data Bank of CSO.

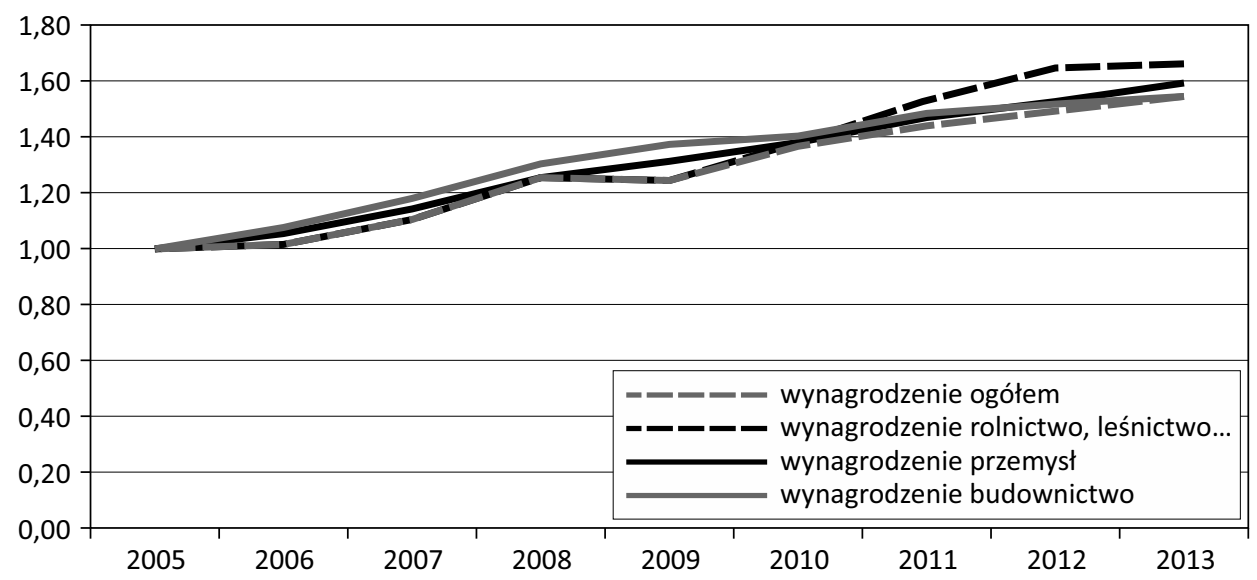

Rysunek 5. Porównanie dynamiki wynagrodzenia czynnika pracy w sekcjach (2005 =1) Figure 5. A comparison of labour remuneration dynamics among sectors of the national economy $(2005=1)$

Źródło: opracowanie własne na podstawie BDL GUS.

Source: own study on the basis of the Local Data Bank of CSO. 


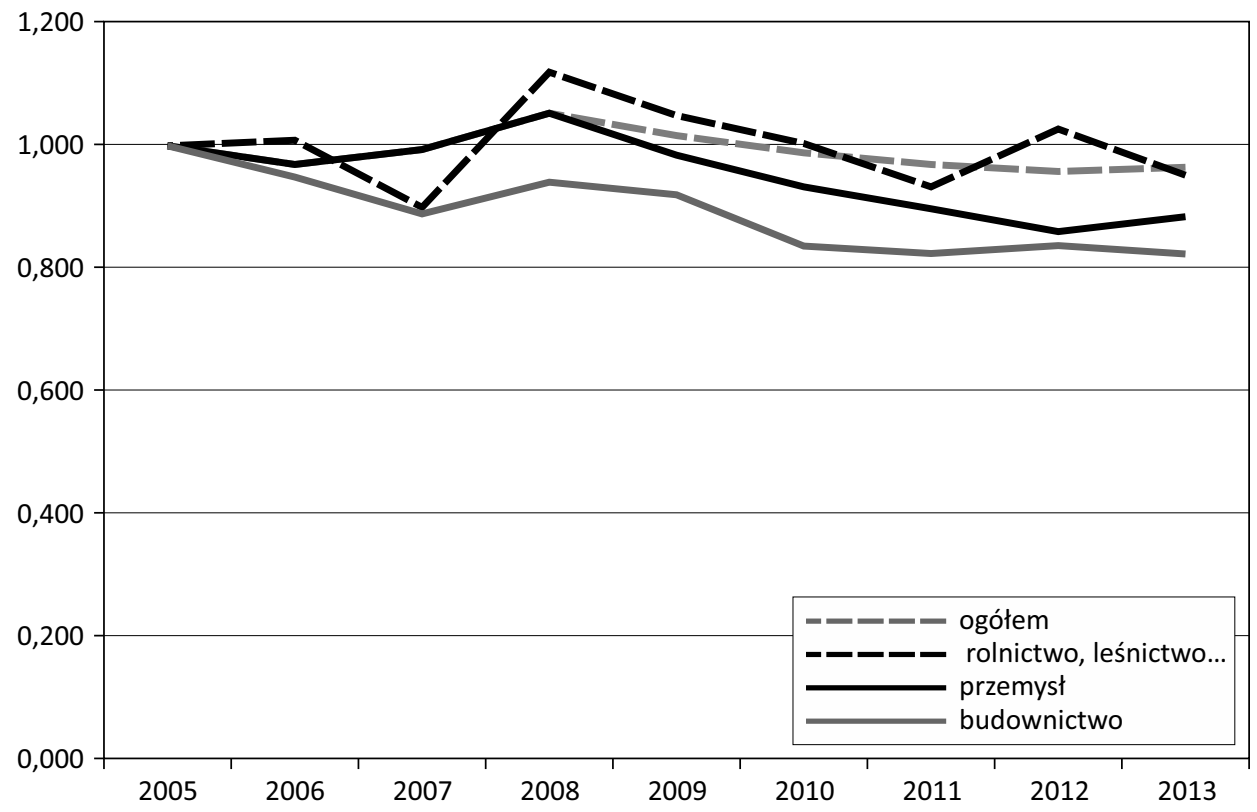

Rysunek 6. Porównanie zmian wynagrodzenia do zmian wydajności czynnika pracy w sekcjach (2005 = 1)

Figure 6. A comparison of dynamics of remuneration change against labour productivity over the time $(2005=1)$

Źródło: opracowanie własne na podstawie BDL GUS.

Source: own study on the basis of the Local Data Bank of CSO.

Dla potwierdzenia powyższych pozytywnych konstatacji i dla lepszego zobrazowania ich podstaw pokazujemy rysunek 7 , przedstawiający zależność między tempami wzrostu wynagrodzenia i wydajności czynnika pracy. Jak widać, w całej gospodarce i w analizowanych sektorach, także w rolnictwie, tempo wzrostu wydajności czynnika pracy jest wyższe niż tempo wzrostu jego wynagrodzenia (nad prostą - wzrost wydajności szybszy niż wynagrodzeń). Oczywiście jest to jeszcze jeden dowód pozytywnej oceny racjonalności procesów wzrostowych w gospodarce narodowej w Polsce w analizowanym okresie. Odnosi się to też do rolnictwa. 


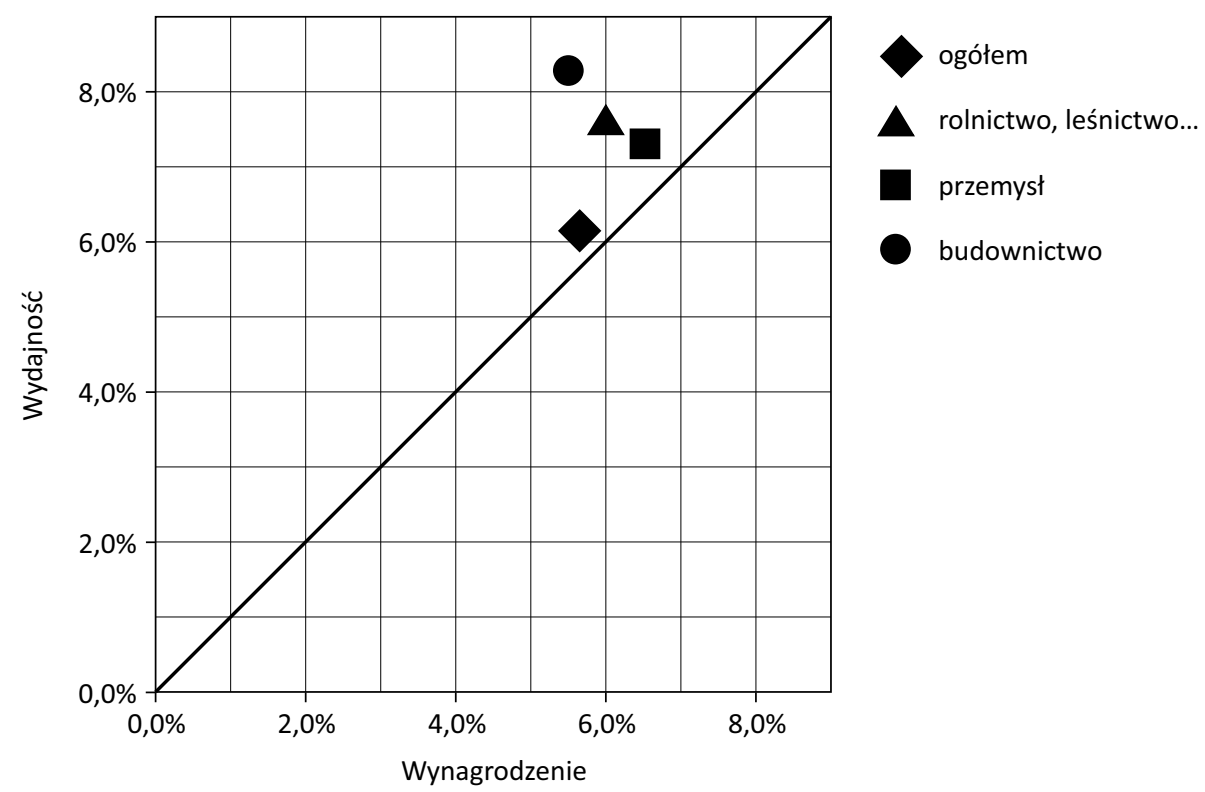

Rysunek 7. Relacje średnich rocznych tempo wzrostu wydajności i wynagrodzenia czynnika pracy w sektorach gospodarki narodowej (2005-2013)

Figure 7. Relationships between the growth rate of remuneration and productivity of labour factor (2005-2013)

Źródło: opracowanie własne na podstawie BDL GUS.

Source: own study on the basis of the Local Data Bank of CSO.

\section{Podsumowanie}

W artykule, którego celem było syntetyczne i ogólne ujęcie wyników pewnego zakresu badań, na podstawie wyprowadzonego autorsko podejścia analitycznego dokonano oceny relacji wynagrodzenia i wydajności czynnika pracy w rolnictwie na tle całej gospodarki narodowej. Ocena tej relacji co do poziomów nie jest korzystna dla rolnictwa, wynagrodzenie jest znacznie wyższe niż wydajność tego czynnika. Zatem czynnik pracy $\mathrm{w}$ rolnictwie jest przeszacowany w stosunku do jego wydajności, podczas gdy w pozostałych sektorach i całej gospodarce narodowej niedoszacowany pod tym względem. Rolnictwo nie jest zatem poszkodowane $\mathrm{w}$ procesie podziału, a wręcz odwrotnie. Taka relacja między wynagrodzeniem a wydajnością czynnika pracy w rolnictwie nie świadczy pozytywnie o racjonalności gospodarowania, w sensie równowag producentów, i nie jest dobrą podstawą dla konkurencyjności. Pozytywny jest natomiast obraz w odniesieniu do rolnictwa, 
przy jeszcze bardziej pozytywnej ocenie pozostałych sektorów i całej gospodarki w odniesieniu do relacji między wzrostem wynagrodzenia i wydajności czynnika pracy. Rolnictwo nie odbiega tu od reszty gospodarki narodowej, wzrost wynagrodzenia czynnika pracy jest zasadniczo finansowany przez wzrost jego wydajności. Jest to pozytywna charakterystyka w sensie równowagi przy ustalonej tej relacji w pobliżu lub poniżej jedności.

\section{Bibliografia}

Bezat-Jarzę̧bowska A., Rembisz W., Sielska A. (2012). Wybór polityki i jej wplyw na decyzje producentów rolnych $w$ ujęciu analitycznym $z$ elementami weryfikacji empirycznej. Warszawa: Instytut Ekonomiki Rolnictwa i Gospodarki Żywnościowej - Państwowy Instytut Badawczy.

Bezat-Jarzebowska A., Rembisz W., Sielska A. (2013). Wplyw polityki rolnej na decyzje producentów rolnych odnośnie dochodów i inwestycji. Warszawa: Instytut Ekonomiki Rolnictwa i Gospodarki Żywnościowej - Państwowy Instytut Badawczy.

Rembisz W. (2013). Kwestie ryzyka, cen, rynku, interwencji i stabilności dochodów w rolnictwie. Warszawa: Vizja Press\&It.

Rembisz W., Floriańczyk Z. (2014). Modele wzrostu gospodarczego w rolnictwie. Warszawa: Instytut Ekonomiki Rolnictwa i Gospodarki Żywnościowej - Państwowy Instytut Badawczy.

Rembisz W., Sielska A. (2014a). Wybrane wskaźniki ekonomiczne w rolnictwie jako skutek długookresowej polityki rolnej $i$ uwarunkowań popytowych. Warszawa: Instytut Ekonomiki Rolnictwa i Gospodarki Żywnościowej - Państwowy Instytut Badawczy.

Rembisz W., Sielska A. (2014b). Renta polityczna a inwestycje oraz relacje wynagrodzenia i wydajności czynnika pracy u producentów rolnych. W: Kowalski A., Wigier M., Wieliczko B. (red.). WPR a konkurencyjność polskiego i europejskiego sektora żywnościowego (s. 15-27). Warszawa: Instytut Ekonomiki Rolnictwa i Gospodarki Żywnościowej - Państwowy Instytut Badawczy.

Rembisz W., Sielska A. (2015). Mikroekonomia współczesna. Warszawa: Vizja Press\&It.

Rembisz W., Sielska A., Pawłowska A. (2016). Jednostkowe koszty pracy w rolnictwie w ujęciu przestrzennym. Artykuł złożony do druku w: Studia Ekonomiczne, Zeszyty Naukowe Uniwersytetu Ekonomicznego w Katowicach.

Skousen M. (2012). Narodziny wspótczesnej ekonomii. Żywoty i idee wielkich myślicieli. Warszawa: Fijorr Publishing. 


\title{
Relationship between Labour Productivity and Its Remuneration in Agriculture in Comparison with National Economy and Its Sectors in Poland in the Period 2005-2012
}

\begin{abstract}
The Author discusses the relationship between the productivity of the labour factor and its remuneration. The analysis is focused on a comparison of agriculture to the national economy and its selected sectors. Both static and dynamic approaches are applied. The relationship between the productivity of the labour factor and its remuneration gives information whether the remuneration results from the productivity.

Producer's equilibrium, zero profit conditions and the problem of the allocation and distribution in the sectoral perspective are the theoretical basis for such an analysis. It is demonstrated whether (and to what extent) labour productivity is the source of funding remuneration in a given sector. Secondly, the analysis allows to assess rationality of the allocation of the labour factor and distribution of value added among sectors. The results can indicate i.a. whether agriculture benefits or loses from such a distribution. The analysis consists of two parts. In the first step the Author derives analytical formulas similar to the idea of the unit labour costs and presents theoretical proof. In the second step, empirical study is conducted based mainly on the graphical illustration.
\end{abstract}

Key words: relations between labour productivity and its remuneration; unit labour cost 